\title{
MEDIEVAL CORNWALL
}

L. E. ELLIOTT-BINNS, D.D., F.R.HIST.S.

'A readable and sympathetic book on what might have been thought a remote and esoteric subject.' A. L. Rowse in Time and Tide.

'He covers his ground thoroughly : few Cornish historians have done this, most of them having been preoccupied with particular localities.' Sir John Squire in The Illustrated London Nerws.

' $\mathrm{He}$ presents a unity to the mind, and it is the recognition of this fundamental unity grounded in religion which lends to a scholarly book its basic authority.' The Tablet.

'A splendid work of historic scholarship, the product of humane learning and deep Christian conviction. It has, moreover, remarkable literary distinction.' The Church Times.

\section{METHUEN}

\section{The Background of the New Testament \& its Eschatology}

\author{
EDITED BY
}

W. D. DAVIES

AND

D. DAUBE

These studies, presented to Dr C. H. Dodd, were written by twenty-six scholars of all denominations to honour a great scholar and teacher.

70s. net

\section{CAMBRIDGE} UNIVERSITY PRESS

\section{A NEW SERIES}

THE EPWORTH PREACHER'S COMMENTARIES

each 8s. 6d. net

Gen. Editor:

GREVILLE P. LEWIS, B.A., B.D.

We are proud to announce a volume on Romans by $\mathrm{Dr}$ Vincent Taylor, as the first volume in this series. Dr Taylor has an unrivalled name as Biblical scholar and commentator.

\section{THE FORMATION OF THE PAULINE CORPUS OF LETTERS}

By C. Leslie Mitton, M.TH., PH.D. 8s.6d. net

We know a great deal about the Apostle Paul, and are also reasonably well informed about the circumstances connected with the writing of his letters. This is an able, scholarly and illuminating discussion of the way in which the Pauline Letters were gathered together.

THE EPWORTH PRESS 25-35 City Road, London, E.C. 1 


\section{OXFORD SPRING BOOKS}

\section{St John's Gospel: A Commentary With the Revised Version Text \\ BY THE LATE R. H. LIGHTFOOT EDITED BY C. F. EVANS}

This book assumes no special linguistic equipment such as a knowledge of Greek, but is a religious and theological exposition of the text of St John's Gospel-a task for which the author was well qualified by his combination of deep faith, meticulous scholarship, and great gifts as a teacher. $\mathrm{Mr}$ Evans has set the Introduction in order and contributed a Preface.

3os. net

By the same author:

The Gospel Message of St Mark I5s. net

\section{The Suffering Servant in Deutero-Isaiah An Historical and Critical Study}

BY C. R. NORTH

\section{Second edition}

The first edition appeared in 1948 . This second edition has been revised and enlarged. What is substantially the author's article on 'Current Scandinavian Discussions' in The Scottish fournal of Theology, iii, 1950, has (by permission of the editors of the Gournal) been substituted for the Postscript to the First Edition.

25s, net

'A thorough, competent and exhaustive study of the whole subject, indispensable to the Old Testament student, and of special interest (because of the author's own solution) to the New Testament student.' The Society for Old Testament Study Book List, reviewing the First Edition.

\section{Already Published}

\section{Jesus and the First Three Gospels}

BY WALTER E. BUNDY

Professor Bundy has already edited a synopsis of the first three Gospels and he here re-examines the whole of their contents so as to write in effect a comprehensive commentary on them in one volume, with special reference to the varied oral traditions embodied in them. (Harvard University Press) 36s. net

\section{OXFORD UNIVERSITY PRESS}

